Рівненського державного гуманітарного університету,

м. Рівне, Україна

ORCID: 0000-0002-9355-4584, e-mail: sve-romanyuk@ukr.net

Трофімчук Вероніка

старший викладач кафедри іноземних мов Рівненського державного гуманітарного університету,

м. Рівне, Україна

ORCID: 0000-0002-1068-0746, e-mail:veronika.trof67@gmail.com

\title{
КОРПУСНИЙ ПІДХІД У НАВЧАННІ ІНОЗЕМНИХ МОВ У ЗВО
}

Анотація. У статті висвітлено особливості впровадження здобутків досліджень у галузі корпусної лінгвістики в процес навчання іноземних мов у закладах вищої освіти (ЗВО). Накопичено грунтовний матеріал щодо наукових досліджень в цій галузі. Автори розглядають теоретичні засади корпусного підходу, наводить визначення дидактичних термінів «корпусна лінгвістика», «корпус текстів», «конкорданс». У роботі представлено характеристики основних типів корпусів, наведено приклади корпусів, які можна використовувати у практиці викладання іноземних мов. Окреслено дидактичні аспекти застосування корпусних технологій у навчанні студентів. У статті запропоновано способи застосування корпусного підходу в лінгводидактичних цілях. Зокрема, розглядаються можливості використання корпусних технологій як інструменту формування лексичних, граматичних, фонетичних навичок студентів та засобу підвищення ефективності роботи як викладача, так і студента. А також узагальнюються пріоритети застосування корпусного підходу у навчанні іноземних мов. Представлене дослідження обгрунтовує методичну доцільність впровадження корпусного підходу як інноваційного та ефективного методу для вдосконалення навчання іноземних мов у закладах вищої освіти.

Ключові слова: лінгводидактика, корпусна лінгвістика, корпус текстів, корпусний підхід, корпусні технології, іноземна мова.

Постановка проблеми. У наш час великих інтеграційних $\mathrm{i}$ глобалізаційних трансформацій система освіти України зазнає кардинальних змін. Застосування інноваційних цифрових технологій, зокрема корпусних технологій відкриває нові перспективи в лінгводидактиці. Впровадження здобутків у галузі корпусної лінгвістики в

(C) Романюк C.,

Трофімчук В., 2021 
навчальний процес з іноземної мови є актуальним і ефективним напрямом методичної роботи в ЗВО.

Аналіз останніх досліджень 3 проблеми. Значні напрацювання, які стосуються особливостей використання дидактичного аспекту корпусної лінгвістики мають західні спеціалісти з викладання англійської мови як іноземної (Johns, 1994, O’Keeffe, McCarthy \& Carter, 2007). Серед українських педагогів, які звертають увагу на доцільність використання надбань корпусної лінгвістики в процесі викладання мовних дисциплін, можна виокремити С. Бук (2007), О. Демська-Кульчицька (2005), В. Жуковська (2013), Л. Кунич (2008) та ін.

Мета статті - обгрунтувати доцільність використання корпусного підходу для вдосконалення викладання іноземної мови у ЗВО.

Виклад основного матеріалу дослідження. Корпусний підхід у навчанні базується на здобутках однієї 3 галузей прикладного мовознавства - корпусної лінгвістики, яка займається виявленням закономірностей функціонування мови шляхом побудови, обробки та експлуатації лінгвістичних корпусів за допомогою сучасних комп’ютерних технологій (Жуковська, 2013, с. 9).

Корпусна лінгвістика започаткувала своє становлення як нова галузь сучасного мовознавства у зв'язку із швидким розвитком комп'ютерних технологій та широким застосуванням комп'ютерів у житті людини на початку 1960 року. Перші дослідження лінгвістичних особливостей американського варіанту англійської мови було проведено у 1963 р. у Браунівському університеті (США) У. Френсисом і Г. Кучерою. Чіткість та наочність Браунівського корпусу сприяли його швидкій популяризації та використанню як певного еталону для створення інших корпусів текстів (Синявська та Лісна, 2019, с. 68). Термін «корпусна лінгвістика» ввійшов до наукового вжитку наприкінці XX ст. завдяки публікації в 1984 році збірника наукових праць «Corpus Linguisitcs: Recent Developments in the Use of Computer Corpora in English Language Research» за матеріалами конференції ICAME «Conference on the Use of Computer Corpora in English Language Research» у м. Неймеген (Голландія) у 1983 році (Aarts \& Meijs, 1984).

Під поняттям «корпус текстів» розуміють зібрання текстів певною мовою в письмовій або усній формі в електронному вигляді (O’Keeffe, McCarthy \& Carter, 2007), відібраних за визначеним критерієм, яке певним чином впорядковане, але основною особливістю корпусу є його розмітка (анотування, маркування) (Войтко, 2014, с. 209). Це уніфікований, структурований, розмічений, філологічно компетентний масив мовних даних (Захаров, 2005, с.3), на основі якого можна проводити якісний та кількісний аналіз мовних одиниць (Biber, Conrad \& Reppen, 1998).

За своєю типологією корпуси текстів поділяються на (Саєнко, 2014, c. 183):

дослідницькі - для вивчення різних аспектів функціонування мовної системи; 


\section{Інноватика у вихованні. Випуск 13.Том 1. 2021.}

ілюстративні, в тому числі навчальні (Learner Corpus) - для підтвердження і обгрунтування лінгвістичних фактів;

моніторні - для дослідження динаміки мовного матеріалу, проведення контент-аналізу;

статичні - для дослідження стилів (авторські корпуси або корпуси текстів);

мультимедійні - текст + відео + аудіо;

корпуси паралельних текстів - для порівняльного аналізу оригіналів текстів та перекладу.

Корпуси як джерела найрізноманітнішої лінгвальної інформації відіграють значну роль в методиці викладання іноземної мови.

Застосування корпусного навчання у ЗВО може бути втілене різними способами (Wichmann, 2007):

1.Використання при викладанні у якості окремого навчального предмета.

2.Використання при підготовці навчально-методичних матеріалів, підручників, посібників, у лексикографічній практиці.

3. Використання в освітньому процесі при виконанні студентами завдань, розроблених викладачем на основі корпусів (навчання лексики, граматики, аудіювання, читання, письма тощо).

4.Використання для індивідуальних дослідницьких проектів студентів, в яких їм пропонується вибрати тему, надати контекстуальні зразки з корпусу та провести власний аналіз.

Найзручнішими для користування у процесі навчання вважаються British National Corpus Sampler, The Longman Corpus, Gutenberg Texts та ін. Найбільш ефективними i перспективними навчальними корпусами $\epsilon$ Learner Corpora і паралельні електронні корпуси текстів Parallel Corpora, які становлять підгрунтя дидактично-орієнтованої корпусної лінгвістики.

Робота 3 корпусом будується на використанні результатів конкордансу, пошукової програми, що аналізує тексти корпусу здійснюючи пошук слів, словосполучень та граматичних конструкцій. Результати пошуку відображаються у вигляді фрагментів різних текстів, 3 яких студенти отримують достатню кількість прикладів використання слова, словосполучення чи граматичної конструкції в реальному (не штучно створеному, навчальному) мовному середовищі (Корницька, 2018).

Корпусний підхід сприяє покращенню роботи як викладача, так i студентів. Головним для викладача є розробка завдань на основі корпусу, координація роботи та мотивація студентів до проведення власного унікального дослідження.

Викладач на основі учнівських корпусів текстів має змогу:

скласти перелік ключових слів, необхідних для професійного спілкування у певній галузі, визначити найбільш вживані словосполучення, фрази, дискурсивні маркери, граматичні форми і на основі цього розробити відповідний комплекс вправ (Маслова, 2016); 


\section{Інноватика у вихованні. Випуск 13.Том 1. 2021.}

скласти перелік активної лексики студентів;

скласти словники термінів для професійно-орієнтованого навчання іноземної мови;

виявляти та аналізувати основні лексичні помилки у студентів, види контекстів, у яких вони найчастіше зустрічаються, та розробити ефективні методи запобігання труднощів і покращення навчання іноземних мов;

використовувати матеріали при укладанні підручників та посібників 3 іноземної мови, забезпечуючи реалізацію принципів професійної спрямованості, автентичності, репрезентативності та частотності мовного матеріалу.

У свою чергу студенти, використовуючи лінгвістичний корпус, розвивають лексико-граматичні навички в рамках проблемного підходу до навчання. Завдання студентів - проаналізувати мовленнєвий матеріал, щоб отримати інформацію про правила вживання певної лексичної одиниці або граматичної структури, з'ясувати семантику слова, особливості полісемії слів, сполучуваності, керування дієслів, вживання часових форм тощо (Маслова, 2016).

Також корпусний підхід до навчання можна застосувати 3 метою підвищення фонологічної компетентності студентів ЗВО. Студентам надається можливість порівняти озвучені рядки конкордансу 3 власним мовленням за допомогою таких завдань: прослуховування уривків, а потім повторення їх самостійно; читання уривків разом 3 диктором одночасно; записати власну версію читання уривку, щоб порівняти іï 3 корпусним сегментом (Babych, 2015).

Корпусний підхід передбачає суттєву зміну ролей викладача та студента. Викладачеві спочатку потрібно навчити студентів працювати 3 корпусами, а надалі контролювати їх самостійну дослідницьку діяльність 3 виявлення граматичних правил або мовних закономірностей. Завдання студентів навчитися вчитися. Отримані студентами знання в процесі самостійної діяльності грунтовніші від наданих викладачем, оскільки, кожен студент безпосередньо працює 3 матеріалом, зосереджує на ньому увагу та максимально мобілізує власні інтелектуальні та емоційні ресурси (Корницька, 2018).

Отже, до переваг застосування корпусних технологій належать такі чинники (O’Keeffe, McCarthy \& Carter, 2007):

можливість оперувати великою репрезентативною добіркою текстів;

дозволяє вивчати реальні слововживання в природному мовленнєвому середовищі;

застосування якісного лінгвістичного аналізу текстового матеріалу;

прикладний характер дослідження, 3 подальшим впровадженням у навчальний процес;

легка адаптованість до інформаційно-комунікаційних технологій та програм-конкордансів;

забезпечення умов інтерактивності в процесі викладання іноземних мов; 
служать підгрунтям для розробки завдань, що сприяють розвитку основних компетенцій у навчанні студентів;

позитивний вплив на засвоєння навчального матеріалу, відібраного відповідно до потреб студентів;

активізація самостійної роботи студентів;

підвищення ефективності навчання.

Висновки і перспективи подальших розвідок. Корпусний підхід $\epsilon$ перспективним напрямом в галузі викладання іноземних мов у ЗВО, що дає можливість впровадження корпусних технологій в навчальний процес та науково-дослідну роботу. Методи корпусної лінгвістики можуть слугувати підгрунтям для інноваційних дидактичних розробок, направлених на створення підручників та навчально-методичних посібників. Перспектива подальших розвідок полягає в дослідженні нових інструментів формування комунікативної компетенції студентів, які мають значний потенціал для підвищення якості іншомовної підготовки майбутніх фахівців.

\section{СПИСОК ВИКОРИСТАНИХ ДЖЕРЕЛ}

Johns, T. (1994). From printout to handout: Grammar and vocabulary teaching in the context of data-driven learning. Perspectives on Pedagogical Grammar. New York: Cambridge University Press. PP. 293-313.

O'Keeffe, A., McCarthy, M. \& Carter, R. (2007). From Corpus to Classroom. Cambridge: Cambridge University Press, 315 p.

Бук, С. (2007). Корпус текстів Івана Франка: спроба визначення основних параметрів. В: Прикладна лінгвістика та лінгвістичні технологї̈: MegaLing-2006, Київ: Довіра. СС. 72-82.

Демська-Кульчицька, О. (2005). Основи національного корпусу української мови: монографія. К.: Інститут української мови НАН України, $218 \mathrm{c}$.

Жуковська, В. (2013). Вступ до корпусної лінгвістики: навчальний посібник. Житомир: ЖДУ ім. І. Франка, 142 с.

Кунич, Л. (2008). Інноваційні технології англійської мови у світлі ідей корпусної лінгвістики. Імідж сучасного педагога, № 9-10. СС. 93-95.

Синявська, А., Лісна, Т. (2019). Дидактичний аспект використання лінгвістичних корпусів у процесі навчання іноземної мови. Теоретичні $\check{u}$ прикладні проблеми сучасної філологї̈, 2(9). СС. 66-73.

Aarts, J. and Meijs, W. (ed). (1984). Corpus Linguistics: Recent Developments in the Use of Computer Corpora in English Language Research. Amsterdam: Rodopi, 229 p.

Войтко, Г. (2014). Корпусна лінгвістика: історія формування i перспективи розвитку. В: Науковий вісник Східноєвропейського національного університету імені Лесі Украӥнки, вип.5. СС. 208-212.

Захаров, В. (2005). Корпусная лингвистика: Учебно-метод. пособие. Санкт-Петербург, 48 с. 


\section{Інноватика у вихованні. Випуск 13.Том 1. 2021.}

Biber, D., Conrad, S. and Reppen, R. (1998). Corpus linguistics: Investigating language structure and use. New York: Cambridge University Press, $250 \mathrm{p}$.

Саєнко, Н. (2014). Формування самоконтролю студентів у розвиваючому навчанні іноземних мов. В: Педагогічна освіта: теорія $i$ практика, 1(16), Кам'янець-Подільський/ СС.182-187.

Wichmann, A. (2007). Corpora and spoken discourse. Language and computers studies in practical linguistics, 62(1). CC. 73-74.

Корницька, Ю. (2018). Лінгвістичний корпус в навчанні іноземних мов. [pdf] Київ: КПI ім. I. Сікорського URL: http://www.kamts1.kpi.ua/ru/node/2459 (дата звернення 21.012021).

Маслова, Т. (2016). Інструменти корпусної лінгвістики у навчанні і дослідженні іноземних мов. [pdf] Київ: КПI ім. I. Сікорського URL: http://www.kamts1.kpi.ua/sites/default/files/files/maslova_instrumenty.pdf [Дата звернення 21.01.21].

Babych, S. (2015). Textual cohesion patterns for developing reading skills. Multiple affordances of language corpora for data-driven learning, Vol. 69, PP. 155-182.

\section{REFERENCES}

Johns, T. (1994). From printout to handout: Grammar and vocabulary teaching in the context of data-driven learning. Perspectives on Pedagogical Grammar. New York: Cambridge University Press. PP. 293-313.

O'Keeffe, A., McCarthy, M. and Carter, R. (2007). From Corpus to Classroom. Cambridge: Cambridge University Press, 315 p.

Buk, S. (2007). Korpus tekstiv Ivana Franka: sproba vyznachennia osnovnykh parametriv [Corpus of texts by Ivan Franko: an attempt to determine the basic parameters]. V: Prykladna linhvistyka ta linhvistychni tekhnolohii: MegaLing 2006, Kyiv: Dovira. SS. 72-82 [in Ukrainian].

Demska-Kulchytska, O. (2005). Osnovy natsionalnoho korpusu ukrainskoi movy [Fundamentals of the national corpus of Ukrainian language]: monohrafiia. Kyiv: Institute of Ukrainian language of National Academy of Sciences of Ukraine. 218 s. [in Ukrainian].

Zhukovska, V. (2013). Vstup do korpusnoi linhvistyky [Introduction to corpus linguistics]: navchalnyi posibnyk. Zhytomyr: Zhytomyr State University named after I. Franko. 142 s. [in Ukrainian].

Kunych, L. (2008). Innovatsiini tekhnolohii anhliiskoi movy u svitli idei korpusnoi linhvistyky [Innovative technologies of English language in the light of the ideas of corpus linguistics]. Imidzh suchasnoho pedahoha, No 9-10. SS. 93-95. [in Ukrainian].

Syniavska, A., Lisna, T. (2019). Dydaktychnyi aspekt vykorystannia linhvistychnykh korpusiv u protsesi navchannia inozemnoi movy [Didactic aspect of linguistic corpora usage in the process of foreign language studies]. Teoretychni y prykladni problemy suchasnoi filolohii, 2 (9). SS.66-73 [in Ukrainian]. 


\section{Інноватика у вихованні. Випуск 13.Том 1. 2021.}

Aarts, J. and Meijs, W. (ed). (1984). Corpus Linguistics: Recent Developments in the Use of Computer Corpora in English Language Research. Amsterdam: Rodopi, 229 p.

Voitko, H. (2014). Korpusna linhvistyka: istoriia formuvannia i perspektyvy rozvytku [Corpus linguistics: history of formation and prospects of development]. V: Naukovyi visnyk Skhidnoievropeiskoho natsionalnoho universytetu imeni Lesi Ukrainky, vyp. 5. SS. 208-212. [in Ukrainian].

Zakharov, V. (2005). Korpusnaya lingvistika [Corpus linguistics]: Uchebno-metod. posobiye. St. Petersburg. 48 s. [in Russian].

Biber, D., Conrad, S. and Reppen, R. (1998). Corpus linguistics: Investigating language structure and use. New York: Cambridge University Press, $250 \mathrm{p}$.

Saienko, N. (2014). Formuvannia samokontroliu studentiv u rozvyvaiuchomu navchanni inozemnykh mov [Formation of students' selfcontrol in developmental foreign language learning]. Pedahohichna osvita: teoriia i praktyka, 1(16), Kamianets-Podilskyi. SS. 182-187. [in Ukrainian].

Wichmann, A. (2007). Corpora and spoken discourse. Language and computers studies in practical linguistics, 62(1), cc. 73-74 [in English].

Kornytska, Yu. (2018). Linhvistychnyi korpus v navchanni inozemnykh mov [Linguistic corpus in foreign language teaching]. [pdf] Kyiv: KPI im. I. Sikorskoho. URL: http://www.kamts1.kpi.ua/ru/node/2459 [Data zvernennia 21.01.21]. [in Ukrainian].

Maslova, T. (2016). Instrumenty korpusnoi linhvistyky u navchanni $i$ doslidzhenni inozemnykh mov [Tools of corpus linguistics in teaching and research of foreign languages]. [pdf] K.: KPI im. I. Sikorskoho. URL: http://www.kamts1.kpi.ua/sites/default/files/files/maslova_instrumenty.pdf (data zvernennia 21.01.21). [in Ukrainian].

Babych, S. (2015). Textual cohesion patterns for developing reading skills. Multiple affordances of language corpora for data-driven learning, Vol. 69. PP. 155-182. 
CORPUS APPROACH IN LEARNING FOREIGN LANGUAGES IN HIGHER EDUCATION INSTITUTIONS

\author{
Svitlana Romaniuk \\ Candidate of Philological Sciences, Associate Professor, \\ Associate Professor at Foreign Languages Department, \\ Rivne State University for the Humanities, \\ Rivne, Ukraine \\ ORCID: 0000-0002-9355-4584 \\ e-mail:sve-romanyuk@ukr.net \\ Veronika Trofimchuk \\ Senior Lecturer at Foreign Languages Department, \\ Rivne State University for the Humanities, \\ Rivne, Ukraine \\ ORCID: 0000-0002-1068-0746, \\ e-mail:veronika.trof67@gmail.com
}

\begin{abstract}
The article highlights the peculiarities of the implementation of research achievements in the field of corpus linguistics in the process of learning foreign languages in higher education institutions. Substantional material on scientific exploration in this field has been collected. The authors consider the theoretical principles of corpus approach, provides definitions of didactic terms "corpus linguistics", "corpus texts", "concordance". The paper presents the characteristics of the basic types of corpora, provides examples, which have the most possibilities of their application for vocabulary, grammar and phonetic studies. Didactic aspects of corpus technologies application in teaching students are outlined. The article proposes ways to apply the corpus approach for linguodidactic purposes. In particular, the possibilities of using corpus technologies as a tool for the formation of communicative competence and means of improving the efficiency of both teachers and students are considered. And also the priorities of application of the corpus approach in learning foreign languages are generalized. The presented research substantiates the methodological expediency of introducing the corpus approach as an innovative and effective method for improving learning foreign languages in higher education institutions. In our time of great integration and globalization transformations, the education system of Ukraine is undergoing radical changes. The use of innovative digital technologies, in particular corpus technologies, opens new perspectives in linguodidactics. The introduction of achievements in the field of corpus linguistics in the educational process of foreign languages is a relevant and effective direction of methodical work in higher education institutions.
\end{abstract}

Keywords: linguodidactics, corpus linguistics, corpus texts, corpus approach, corpus technologies, foreign language.

Стаття надійшла до редакиії 17. 02. 2021p. 